\title{
Effect of curing ingredients and vacuum packaging on the physico- chemical and storage quality of ready-to-eat Vawksa rep (smoked pork product) during refrigerated storage
}

\author{
Deepshikha Deuri ${ }^{1}$, Pragati Hazarika ${ }^{1}$, Tarun Pal Singh ${ }^{2}$, Lalchamliani Chhangte ${ }^{2}$, Parminder Singh ${ }^{3}$ and Suman Talukder ${ }^{2}$
}

1. Division of Livestock Products Technology, College of Veterinary Sciences and Animal Husbandry, CAU, Selesih, Aizawl, Mizoram, India; 2. Division of Livestock Products Technology, Indian Veterinary Research Institute, Izzatnagar, Bareilly, Uttar Pradesh, India; 3. Veterinary Officer, Department of Animal Husbandry, Government of Punjab, Amritsar, Punjab, India.

Corresponding author: Deepshikha Deuri, e-mail: drdeuri10@gmail.com,

PH: pragati.h@rediffmail.com, TPS: tarunsingh835@gmail.com, LC: drchami17@gmail.com, PS: pssandhulpt@gmail.com, ST: drttalukder@gmail.com

Received: 25-01-2016, Accepted: 28-04-2016, Published online: 12-06-2016

doi: 10.14202/vetworld.2016.587-594 How to cite this article: Deuri D, Hazarika P, Singh TP, Chhangte L, Singh P, Talukder S (2016) Effect of curing ingredients and vacuum packaging on the physico-chemical and storage quality of ready-to-eat Vawksa rep (smoked pork product) during refrigerated storage, Veterinary World, 9(6): 587-594.

\begin{abstract}
Aim: The present study was conducted for the development of ready-to-eat Vawksa rep (smoked pork product) and to study the synergistic effect of curing ingredients and vacuum packaging on the physico-chemical and storage quality during refrigerated storage at $\left(4^{\circ} \mathrm{C} \pm 1^{\circ} \mathrm{C}\right)$ for 15 days.

Materials and Methods: Four different batches of Vawksa rep samples were prepared, i.e., T-1 (uncured, first cooked at $121^{\circ} \mathrm{C}$ for $15 \mathrm{~min}$, and then smoked at $120^{\circ} \mathrm{C}$ for $30 \mathrm{~min}$ ), T-2 (uncured, cooked, and smoked simultaneously at $120^{\circ} \mathrm{C}$ for $45 \mathrm{~min}$ ), T-3 (cured, first cooked at $121^{\circ} \mathrm{C}$ for $15 \mathrm{~min}$, and then smoked at $120^{\circ} \mathrm{C}$ for $30 \mathrm{~min}$ ), and T-4 (cured, cooked, and smoked simultaneously at $120^{\circ} \mathrm{C}$ for $45 \mathrm{~min}$ ).

Results: Cooking yield was significantly higher $(\mathrm{p}<0.05)$ for the T-4. The $\mathrm{pH}$ of T-3 and T-4 samples was significantly higher $(p<0.05)$ on day 15 . The tyrosine value of all the samples increased significantly $(p<0.05)$ among the different days of analysis. Thiobarbituric acid value was significantly $(\mathrm{p}<0.05)$ lower in T-3 sample both at the beginning and at the end of storage period. In microbiological profile, total plate count was lower in T-3 and T-4 than T-1 and T-2. However, Escherichia coli count was negative for T-3 and T-4 samples throughout the storage period. Among sensory attributes, T-3 and T-4 samples registered superior scores for color, flavor, texture, juiciness, and overall acceptability.
\end{abstract}

Conclusion: Furthermore, Vawksa rep (smoked pork product) could be prepared easily with little technology up-gradation and with a negligible escalation of production cost.

Keywords: curing, smoking, storage quality, vacuum packaging, Vawksa rep.

\section{Introduction}

Meat is a highly perishable commodity due to a rich source of nutrients. Color, microbial growth, and lipid oxidation are considered important factors for limiting the shelf-life and consumer acceptance of meat and meat products [1]. Thus for extending the shelf-life, the use of a combination technology of different processing, packaging, and preservation conditions is a need of the hour.

Smoking is one of the oldest food processing technologies which not only improve the sensory quality but also inactivates a number of enzymes and microflora [2]. The active components of smoking which produce these activities are phenols, carbonyls, acids, alcohols, esters, lactones, polycyclic aromatic

Copyright: Deuri, et al. Open Access. This article is distributed under the terms of the Creative Commons Attribution 4.0 International License (http://creativecommons.org/licenses/by/4.0/), which permits unrestricted use, distribution, and reproduction in any medium, provided you give appropriate credit to the original author(s) and the source, provide a link to the Creative Commons license, and indicate if changes were made. The Creative Commons Public Domain Dedication waiver (http://creativecommons.org/ publicdomain/zero/1.0/) applies to the data made available in this article, unless otherwise stated. hydrocarbons, pyrazines, pyrrole, and furan derivatives [3]. It mainly improves color, odor and texture (firmness/hardness), physico-chemical, and microbial quality. However, smoking is often coupled with curing, salting, packaging, and chilling techniques to produce synergistic effects toward spoilage micro-organisms and to increase the shelf-life [4]. Vacuum packaging of meat is meant to retard or completely check the oxidative reactions and inhibit the microbial growth by reducing the amount of oxygen in contact with the product. Vacuum packaging preserves the natural flavor of the product, in addition to a number of advantages including such as saving of space and energy during storage, transport and distribution, reduction in weight loss, better-keeping qualities, and better display of the product [5].

Ready-to-eat food products form an important part of the diet in our day-to-day life. Vawksa rep, not ready-to-eat but a ready-to-cook smoked pork product, is one of the most popular traditional meat products of Mizoram. "Sa-rep" means "smoked meat" (where " $\mathrm{Sa}$ " stands for meat and "rep" means dehydrated or dry ones in Mizo language) is prepared 
locally in Mizoram and is preferred and widely consumed by the majority of middle-class income Mizo people [6]. It is prepared by mild smoking (2-3 h) of pork chunks of almost uniform size. The problem associated with Vawksa rep is that it has a short shelflife because pork is highly prone to lipid oxidation due to the presence of excessive amounts of fat in it, and second, no other processing and preservation (except smoking) treatments are applied to this product for prolonging its shelf-life. Moreover, the product is sold without proper packaging, thereby increasing the chances of physical, chemical, and microbial contamination, in addition to fat oxidation. Keeping in view of the above-mentioned problems, the present study was undertaken for the development of ready-to-eat Vawksa rep and to study the synergistic effect of curing, smoking, and vacuum packaging on the physico-chemical, sensory, and microbial quality during refrigerated storage conditions.

\section{Materials and Methods}

\section{Preparation of Vawksa rep meat samples}

Raw pork cuts (hams) were purchased from the freshly slaughtered Yorkshire pig carcasses of about 8 months to 1 year of age from local market. In the laboratory, these were cut into small pieces of uniform size $\left(3^{\prime \prime} \times 3^{\prime \prime}\right)$ with the help of a knife. Traditional Vawksa rep was prepared by piercing the pork chunks to the wooden stick and then placing the meat chunks $30 \mathrm{~cm}$ above the fire for $45 \mathrm{~min}$. Hardwood was used for smoking of meat. Uncured pork chunks were first pressure cooked at $121^{\circ} \mathrm{C}$ for $15 \mathrm{~min}$ and subsequently smoked (CS) in the smoke unit (Kerres Showsmoker $\mathrm{CS} 350 \mathrm{EL})$ for $30 \mathrm{~min}$ at $120^{\circ} \mathrm{C}(\mathrm{T}-1)$; cooked and smoked simultaneously (Directly smoked, DS) in the smoke unit at $120^{\circ} \mathrm{C}$ for $60 \mathrm{~min}(\mathrm{~T}-2)$. The pork chunks of uniform sizes $\left(3^{\prime \prime} \times 3^{\prime \prime}\right)$ were cured for $24 \mathrm{~h}$ using curing mixture (Table-1). Cured pork chunks were pressure cooked at $121^{\circ} \mathrm{C}$ for $15 \mathrm{~min}$ and subsequently smoked in the smoke unit for $30 \mathrm{~min}$ at $120^{\circ} \mathrm{C}$ (T-3); cooked and smoked simultaneously in the smoke unit at $120^{\circ} \mathrm{C}$ for $45 \mathrm{~min}$ (T-4). These treatments were packed and sealed using the vacuum packaging machine in high-density polyethylene (HDPE, 3 Mil) bags and kept at refrigeration temperature $\left(4^{\circ} \mathrm{C} \pm 1^{\circ} \mathrm{C}\right)$ for 15 days. The samples were analyzed for different physico-chemical, sensory, and microbiological quality parameters at $1,5,10$, and 15 days.

Table-1: Formulation for marination of pork chunks.

\begin{tabular}{lc}
\hline Ingredients & Quantity \\
\hline Salt & $1.5 \%$ \\
Sodium nitrate $\left(\mathrm{NaNO}_{3}\right)$ & $200 \mathrm{mg} / \mathrm{kg}$ \\
Sodium nitrite $\left(\mathrm{NaNO}_{2}\right)$ & $150 \mathrm{mg} / \mathrm{kg}$ \\
Spice-mix & $2 \%$ \\
Sodium tripolyphosphate & $0.5 \%$ \\
Yoghurt & $10 \%$ \\
Sugar & $1.5 \%$ \\
\hline
\end{tabular}

\section{Physico-chemical quality parameters}

Cooking yield

Cooking yield was calculated by dividing the weights of raw and cooked sample before with that of after cooking, multiplied by 100 .

\section{Cooking loss}

Cooking loss was calculated by subtracting weight of the cooked product from the weight of the raw pork chunks.

$p H$

The $\mathrm{pH}$ of the sample was determined using a pH meter (Cyberscan 1000 Euteoh Instruments) and by following the methods as described by Bendall [7].

\section{Texture analysis}

Texture of the samples was analyzed using food texture analyzer (TA HD- Plus) with a load cell of $250 \mathrm{~kg}$ on different days of analysis. Measurements were taken at room temperature with a sample size of $2 \times 2 \mathrm{~cm}^{3}$. Data collection and analysis were performed using the Texture Expert Stable Micro Systems computer program, version 1.16.

\section{Tyrosine value (TV) and thiobarbituric acid value (TBA)}

TV and TBA were determined as per the standard methods proposed by Pearson [8] and Witte et al. [9], respectively.

\section{Microbiological quality parameters}

Total plate count (TPC), coli titer count, and E. coli counts of the samples were performed following the methods as described by APHA [10]. The average number of colonies was multiplied by the reciprocal of the dilution and expressed as $\log _{10} \mathrm{cfu} / \mathrm{g}$.

\section{Organoleptic quality parameters} Assessment of odor

All the Vawksa rep meat samples were assessed by a semi-trained panel of 25-30 judges by using a 10 point hedonic scorecard scale [8] on day $1^{\text {st }}$ and thereafter, on $5^{\text {th }}, 10^{\text {th }}$, and $15^{\text {th }}$ days of storage.

\section{Sensory evaluation}

A six member experienced panel of judges evaluated the samples for different sensory attributes, viz., color and appearance, flavor, texture, juiciness, and overall acceptability, using an 8-point descriptive scale [11], where $8=$ excellent and $1=$ extremely poor. On each day of analysis, samples were cooked at $121^{\circ} \mathrm{C}$ for $15 \mathrm{~min}$, cooled and then presented to the panelists for sensory evaluation along with a glass of water for rinsing of mouth.

\section{Statistical analysis}

Data were analyzed statistically on "SPSS16.0" (SPSS Inc., Chicago, II USA) software package as per standard methods [12]. Duplicate samples were drawn for each parameter, and the whole experiment was repeated three times to have total 
number of observations, $\mathrm{n}=6$ for all parameters. The entire data were subjected to two-way analysis of variance along with Duncan's multiple range test, and the significance was studied at $5 \%$ level $(\mathrm{p}<0.05)$.

\section{Results and Discussion}

\section{Physico-chemical quality}

Cooking yields and cooking losses were estimated at day 0 . Statistical analysis revealed that cooking yield was significantly higher $(\mathrm{p}<0.05)$ for the T-4 $\left(84.61 \pm 0.02^{\mathrm{d} \%} \%\right)$ followed by T-2 $\left(82.63 \pm 0.09^{\mathrm{c} \%} \%\right)$, $\mathrm{T}-3\left(82.50 \pm 0.05^{\mathrm{b} \%}\right)$, and T-1 $\left(81.75 \pm 0.05^{\mathrm{a}} \%\right)$. It might be due to the extra uptake of salt and sugar, which were retained during processing, thus increasing water retention in T-4. The cooking loss was significantly higher $(\mathrm{p}<0.05)$ for $\mathrm{T}-1 \quad(18.25 \pm 0.03 \mathrm{~d} \%)$ followed by T-3 $\left(17.50 \pm 0.15^{\mathrm{c}} \%\right), \mathrm{T}-2\left(17.37 \pm 0.03^{\mathrm{bo}} \%\right)$, and T-4 $\left(15.39 \pm 0.09^{\mathrm{a} \%}\right)$. The heat treatment causes more moisture losses from the product, thereby resulting into more loss of meat fluid in T-1. Kanithaporn et al. [13] observed that the cooking loss in fully cooked RTE bacon heated for $30 \mathrm{~s}(20.91 \pm 0.68)$ was lower than that of the RTE bacon heated for $60 \mathrm{~s}$ (24.23 \pm 0.32$)$.

The results for $\mathrm{pH}$, texture analysis (hardness), TV, and TBA are presented in Table- 2 . The mean initial $\mathrm{pH}$ value of raw pork was 6.55 . Initially, the $\mathrm{pH}$ values decreased up to $5^{\text {th }}$ day of storage in all the treatment groups, but thereafter a rise in $\mathrm{pH}$ was observed gradually up to $15^{\text {th }}$ day of storage, except in T-3, where progressive decrease in $\mathrm{pH}$ was recorded on $1^{\text {st }}, 5^{\text {th }}$, and $10^{\text {th }}$ days of storage followed by increased $\mathrm{pH}$ on $15^{\text {th }}$ day of storage. CS samples, i.e., T-1 and T-3 for producing RTE Vawksa rep exhibited higher $\mathrm{pH}$ values compared to the ones who were directly smoked, i.e., T-2 and T- 4 . The $\mathrm{pH}$ of T-3 and T-4 samples was significantly higher $(\mathrm{p}<0.05)$ on day 15 than day 1 . Overall DS samples showed a faster fall in $\mathrm{pH}$ than CS samples of RTE Vawksa rep. Arnim and Marlida [14] also reported increase in $\mathrm{pH}$ values (at the end of storage) of meat balls treated with liquid smoke. Similar findings were observed by Kumar et al. [15] in pork nuggets during their refrigerated storage. The increase in $\mathrm{pH}$ of $\mathrm{T}-1, \mathrm{~T}-2$, and T-4 on $10^{\text {th }}$ and $15^{\text {th }}$ day of storage, respectively, was in agreement with the findings of Karabagias et al. [16]. The variation in $\mathrm{pH}$ with curing ingredients, among the different treatments could be attributed to various factors such as the formation of bacterial metabolites, deamination of proteins, growth of facultative anaerobes, lactic acid bacteria, migration of antimicrobial substances, and formation of carbonic acid in vacuum packaging [17].

In texture profile, with the advancement of the storage period, there was continued and significant $(\mathrm{p}<0.05)$ increase in hardness of all the Vawksa rep samples. In general, higher mean peak forces were required to cut CS as compared to DS RTE Vawksa rep samples. Between CS, i.e. T-1 and T-3; the T-3 (1775.50-2041.70 g) required low force than T-1 (2287.21-2869.17 g). In DS RTE Vawksa rep (T-2 and T-4), a relatively lower force was required in T-4 (1576.60-1712.50 g) as compared to T-2 (1890.41$2683.60 \mathrm{~g})$. Garcia-Esteban et al. [18] also observed continued increase in hardness value of dry cured hams during storage under vacuum packaging conditions, with the highest hardness value $(2669.00 \mathrm{~g})$ observed in vacuum packed samples at the end of storage period. Cilla et al. [19] also observed a hardness value of $5220.99 \mathrm{~g}$ in vacuum packaged dry cured ham cuts stored at $4^{\circ} \mathrm{C} \pm 2^{\circ} \mathrm{C}$.

Table-2: Physico-chemical properties of Vawksa rep (smoked pork product) stored under vacuum packaging conditions at $4^{\circ} \mathrm{C} \pm 1^{\circ} \mathrm{C}$.

\begin{tabular}{lcccc}
\hline Treatments/Days & $\mathbf{1}$ & $\mathbf{5}$ & $\mathbf{1 0}$ & $\mathbf{1 5}$ \\
\hline pH & & & \\
T-1 & $6.50 \pm 0.01^{\mathrm{aA}}$ & $6.45 \pm 0.01^{\mathrm{aA}}$ & $6.54 \pm 0.13^{\mathrm{aA}}$ & $6.60 \pm 0.01^{\mathrm{aA}}$ \\
T-2 & $6.44 \pm 0.01^{\mathrm{aAB}}$ & $6.25 \pm 0.01^{\mathrm{cC}}$ & $6.37 \pm 0.01^{\mathrm{bAB}}$ & $6.45 \pm 0.01^{\mathrm{aB}}$ \\
T-3 & $6.46 \pm 0.02^{\mathrm{aB}}$ & $6.38 \pm 0.01^{\mathrm{bcB}}$ & $6.36 \pm 0.01^{\mathrm{cAB}}$ & $6.40 \pm 0.01^{\mathrm{bC}}$ \\
T-4 & $6.43 \pm 0.01^{\mathrm{aB}}$ & $6.24 \pm 0.01^{\mathrm{dC}}$ & $6.30 \pm 0.01^{\mathrm{cB}}$ & $6.39 \pm 0.01^{\mathrm{bC}}$ \\
Hardness (g) & & & \\
T-1 & $2287.21 \pm 0.06^{\mathrm{dA}}$ & $2687.80 \pm 0.06^{\mathrm{cA}}$ & $2785.80 \pm 0.10^{\mathrm{bA}}$ & $2869.17 \pm 0.32^{\mathrm{aA}}$ \\
T-2 & $1890.41 \pm 0.06^{\mathrm{dB}}$ & $2412.90 \pm 0.10^{\mathrm{cB}}$ & $2577.60 \pm 0.06^{\mathrm{bB}}$ & $2683.60 \pm 0.06^{\mathrm{aB}}$ \\
T-3 & $1775.50 \pm 0.06^{\mathrm{dC}}$ & $1832.90 \pm 0.10^{\mathrm{cC}}$ & $1960.92 \pm 0.11^{\mathrm{bC}}$ & $2041.70 \pm 0.06^{\mathrm{aC}}$ \\
T-4 & $1576.60 \pm 0.10^{\mathrm{dD}}$ & $1650.30 \pm 0.10^{\mathrm{cD}}$ & $1681.40 \pm 0.10^{\mathrm{bD}}$ & $1712.50 \pm 0.14^{\mathrm{aD}}$ \\
TV $(\mathrm{mg}$ tyrosine/100 g) & & & \\
T-1 & $0.058 \pm 0.05^{\mathrm{dB}}$ & $0.075 \pm 0.05^{\mathrm{cB}}$ & $0.089 \pm 0.01^{\mathrm{bB}}$ & $0.150 \pm 0.01^{\mathrm{aB}}$ \\
T-2 & $0.085 \pm 0.08^{\mathrm{dA}}$ & $0.101 \pm 0.01^{\mathrm{cA}}$ & $0.152 \pm 0.06^{\mathrm{bA}}$ & $0.165 \pm 0.09^{\mathrm{aA}}$ \\
T-3 & $0.052 \pm 0.06^{\mathrm{cC}}$ & $0.055 \pm 0.06^{\mathrm{cD}}$ & $0.060 \pm 0.01^{\mathrm{bC}}$ & $0.098 \pm 0.09^{\mathrm{aD}}$ \\
T-4 & $0.059 \pm 0.06^{\mathrm{dB}}$ & $0.065 \pm 0.09^{\mathrm{cC}}$ & $0.087 \pm 0.05^{\mathrm{bB}}$ & $0.103 \pm 0.01^{\mathrm{aC}}$ \\
TBA (mg malondialdehyde/kg) & & & \\
T-1 & $0.28 \pm 0.05^{\mathrm{dA}}$ & $0.34 \pm 0.09^{\mathrm{cA}}$ & $0.65 \pm 0.08^{\mathrm{bC}}$ & $1.21 \pm 0.08^{\mathrm{aB}}$ \\
T-2 & $0.25 \pm 0.01^{\mathrm{dA}}$ & $0.32 \pm 0.05^{\mathrm{cAB}}$ & $0.80 \pm 0.09^{\mathrm{bA}}$ & $1.35 \pm 0.01^{\mathrm{aA}}$ \\
T-3 & $0.30 \pm 0.05^{\mathrm{cB}}$ & $0.75 \pm 0.01^{\mathrm{bB}}$ & $0.80 \pm 0.09^{\mathrm{aD}}$ \\
T-4 & $0.21 \pm 0.08^{\mathrm{dB}}$ & $0.32 \pm 0.05^{\mathrm{cAB}}$ & $0.78 \pm 0.05^{\mathrm{bA}}$ & $0.90 \pm 0.09^{\mathrm{aC}}$ \\
\hline
\end{tabular}

$\mathrm{n}=6$, mean \pm SE with different superscripts row wise (small alphabets) and column wise (capital alphabets) differ significantly $(p<0.05)$. SE=Standard error, TV=Tyrosine value, TBA=Thiobarbituric acid 
The mean initial TV of raw pork was $0.220 \mathrm{mg}$ tyrosine/100 g (0 day). Irrespective of the treatment groups, the TV increased in all the samples throughout the storage period (Table-2). The mean TV of all the samples increased significantly $(p<0.05)$ among the different days of analysis. At the end of the storage period, i.e., day 15 , TV was significantly higher $(\mathrm{p}<0.05)$ in T-2 followed by T-1, T-4, and T-3. Even though all the treatment groups showed a gradual increase in the TV from $1^{\text {st }}$ to $15^{\text {th }}$ day, the DS RTE Vawksa rep exhibited higher TV than the CS RTE Vawksa rep samples. Similar results were reported by Lalchamliani et al. [20] in Vawksa rep samples stored under different aerobic vacuum packaging conditions at $4^{\circ} \mathrm{C} \pm 1^{\circ} \mathrm{C}$. The findings are also in agreement with the statement of Pearson [8], who reported that TV of meat increases with storage period until deamination of amino acid limits the formation of free amino acid.

The TBA value of raw pork was $0.235 \mathrm{mg}$ malondialdehyde $/ \mathrm{kg}$ of meat. In general, TBA values of all the samples increased significantly $(\mathrm{p}<0.05)$ throughout the storage period (Table-2). Compared to other treatments, T-3 sample maintained significantly $(p<0.05)$ lower values of TBA both at the beginning (day 1 ) and at the end (day 15) of storage period. At the end of the storage period, i.e., on day 15, the difference in TBA values of both CS and DS RTE Vawksa rep samples was significantly higher $(\mathrm{p}<0.05)$ than day 1 , 5 and 10 of storage periods. For TBA value, $0.5 \mathrm{mg}$ malondialdehyde $/ \mathrm{kg}$ is considered as the cut-off value for fat oxidation and $1 \mathrm{mg}$ malondialdehyde $/ \mathrm{kg}$ for rancidity in the products. From the Table-2, it is clear that all the treatments of RTE Vawksa rep experienced oxidation on the $10^{\text {th }}$ day of storage. Overall, the combination of smoking and vacuum packaging resisted the lipid oxidation in RTE Vawksa rep. In this study, the increase in TBA values of all the samples was within the threshold limit of 1-2 mg malondialdehyde/kg meat. The increase in TBA value during storage might be attributed to the oxidation of meat lipid or both CS and DS RTE Vawksa rep at refrigeration temperature. Lalchamliani et al. [20] also observed increasing trends in TBA values of Vawksa rep samples during refrigerated storage. Kumar et al. [15] also reported that the TBARS values of pork nuggets significantly $(\mathrm{p}<0.01)$ increased with the increase of storage period. Kumar and Sharma [21] also observed a linear increase in TBA value throughout the storage period while studying the quality characteristics of low-fat ground pork patties containing milk co-precipitate.

\section{Microbiological quality}

The data related to microbiological quality parameters of Vawksa rep are presented in Table-3. The TPC in raw pork was $5.50 \log _{10} \mathrm{cfu} / \mathrm{g}$. There was a continued and significant increase $(\mathrm{p}<0.05)$ in TPC of all the samples from day 1 to 15 , though the increase in the count was relatively less in T-3 and T-4 than T-1 and T-2. Moreover, it was evidenced that smoking caused decrease in the number of the viable aerobic micro-organisms from the initial mean value of raw meat. The increase in the TPC Vawksa rep during storage might be due to increasing in $\mathrm{pH}$ values of the sample, which favored the growth of bacteria. The reduction in the count of aerobic microbes could also be due to the antimicrobial effect of curing ingredients, smoking, and vacuum packaging. The findings are in agreement with the results of Lalchamliani et al. [20] in Vawksa rep meat samples stored at $4^{\circ} \mathrm{C} \pm 1^{\circ} \mathrm{C}$. Irkin et al. [22] also observed that minced beef samples treated with vacuum packaging showed lower viable counts than control. Kumar et al. [15] reported gradual but significant increase in total viable counts throughout the storage period in pork nuggets. Lawrie [23] reported that when smoking was combined with curing, the shelf-life of such products increases and the microbial load decreases especially on the meat surface.

The mean colititer value of raw pork was $780.00 \mathrm{MPN} / \mathrm{g}$. The mean values of colititer counts

Table-3: Microbiological quality of Vawksa rep (smoked pork product) stored under vacuum packaging conditions at $4^{\circ} \mathrm{C} \pm 1^{\circ} \mathrm{C}$.

\begin{tabular}{lcccc}
\hline Treatments/Days & $\mathbf{1}$ & $\mathbf{5}$ & $\mathbf{1 0}$ & $\mathbf{1 5}$ \\
\hline Total plate count $\left(\log _{10} \mathrm{cfu} / \mathrm{g}\right)$ & & & & \\
T-1 & $3.60 \pm 0.06^{\mathrm{dA}}$ & $3.90 \pm 0.06^{\mathrm{cA}}$ & $4.80 \pm 0.04^{\mathrm{bA}}$ & $5.30 \pm 0.06^{\mathrm{aA}}$ \\
T-2 & $3.80 \pm 0.10^{\mathrm{dA}}$ & $4.10 \pm 0.06^{\mathrm{cA}}$ & $4.90 \pm 0.06^{\mathrm{bA}}$ & $5.40 \pm 0.10^{\mathrm{aA}}$ \\
T-3 & $2.51 \pm 0.12^{\mathrm{bB}}$ & $2.60 \pm 0.10^{\mathrm{bB}}$ & $3.50 \pm 0.14^{\mathrm{aB}}$ & $3.80 \pm 0.06^{\mathrm{aB}}$ \\
T-4 & $2.60 \pm 0.10^{\mathrm{bB}}$ & $2.70 \pm 0.06^{\mathrm{bB}}$ & $3.70 \pm 0.13^{\mathrm{aB}}$ & $3.90 \pm 0.06^{\mathrm{aB}}$ \\
Colititer (MPN/g) & & & \\
T-1 & $115.00 \pm 11.69^{\mathrm{dB}}$ & $310.00 \pm 52.09^{\mathrm{cB}}$ & $343.33 \pm 55.29^{\mathrm{bB}}$ & $493.33 \pm 129.07^{\mathrm{aB}}$ \\
T-2 & $134.16 \pm 10.83^{\mathrm{dA}}$ & $353.33 \pm 48.83^{\mathrm{cA}}$ & $386.66 \pm 46.38^{\mathrm{bA}}$ & $530.00 \pm 119.53^{\mathrm{aA}}$ \\
T-3 & $15.00 \pm 0.37^{\mathrm{bC}}$ & $\mathrm{ND}$ & $\mathrm{ND}$ & $\mathrm{ND}$ \\
T-4 & $18.00 \pm 1.71^{\mathrm{bD}}$ & $\mathrm{ND}$ & $\mathrm{ND}$ & $\mathrm{ND}$ \\
E. coli count $\left(\log _{10} \mathrm{cfu} / \mathrm{g}\right)$ & & & \\
T-1 & $1.57 \pm 0.05^{\mathrm{cA}}$ & $1.73 \pm 0.05^{\mathrm{bA}}$ & $1.82 \pm 0.09^{\mathrm{abA}}$ & $1.93 \pm 0.05^{\mathrm{aA}}$ \\
T-2 & $1.62 \pm 0.05^{\mathrm{dA}}$ & $1.75 \pm 0.05^{\mathrm{cA}}$ & $1.85 \pm 0.05^{\mathrm{bA}}$ & $1.98 \pm 0.03^{\mathrm{aB}}$ \\
T-3 & $\mathrm{ND}$ & $\mathrm{ND}$ & $\mathrm{ND}$ & $\mathrm{ND}$ \\
T-4 & $\mathrm{ND}$ & $\mathrm{ND}$ & $\mathrm{ND}$ & $\mathrm{ND}$ \\
\hline
\end{tabular}

$\mathrm{n}=6$, mean \pm SE with different superscripts row wise (small alphabets) and column wise (capital alphabets) differ significantly $(p<0.05) . N D=$ Not detected, $S E=S t a n d a r d$ error, $E$. coli=Escherichia coli 
increased significantly $(\mathrm{p}<0.05)$ in $\mathrm{T}-1$ and $\mathrm{T}-2$. However, in T-3 and T-4 samples, colititer count was detected only on day 1 and was not detected subsequently. Among T-3 and T-4, colititer count was significantly lower $(\mathrm{p}<0.05)$ in $\mathrm{T}-3$ sample. Hence, in terms of microbiological quality, T-3 sample of Vawksa rep was superior to other variants. Irkin et al. [22] reported that the number of coliforms increased slightly in all the minced beef samples until the end of storage and was below the accepted limit (3 $\log _{10} \mathrm{cfu} / \mathrm{g}$ ) except in control samples stored at $4^{\circ} \mathrm{C}$. Bacteriological isolation studies by Chaudhari et al. [6] in Mizoram involving 100 pork "Sa-rep" (smoked meat) samples revealed the presence of $E$. coli only in 9 isolates. The initial mean $E$. coli count was recorded to be $3.12 \log _{10} \mathrm{cfu} / \mathrm{g}$ of meat. There was a significant increase $(\mathrm{p}<0.05)$ in $E$. coli counts in T-1 and T-2 from the mean value of $1.57 \log _{10} \mathrm{cfu} / \mathrm{g}$ and $1.62 \log _{10}$ $\mathrm{cfu} / \mathrm{g}$ on the $1^{\text {st }}$ day to 1.93 and $1.98 \log _{10} \mathrm{cfu} / \mathrm{g}$ on the $15^{\text {th }}$ day of storage, respectively. The $E$. coli count was negative for all the cured CS and DS (T-3 and T-4) products in all the storage periods. The absence of $E$. coli in T-3 and T-4 conforms to the national standard, i.e., nil presence of coliform organisms at $0.001 \mathrm{~g}$ level the for entire storage period.

\section{Organoleptic quality}

Assessment of odor

The odor scores for different treatments decreased significantly with the advancement of the storage period (Table-4). In general, the scores were comparatively higher for T-3 and T-4 than T-1 and T-2. At the beginning of storage period, i.e., day 1 , the odor scores for T-3 and T-4 were similar (9.60), but at the end of the storage period (day 15), the scores were slightly higher $(\mathrm{p}<0.05)$ for T-3 $(7.80)$ than T-4 (7.60). The decrease in odor scores of samples might be due to continue and significant $(\mathrm{p}<0.05)$ increase in TBA value throughout the storage period. Many authors reported similar findings and observed that meat products were acceptable and did not show any perceivable rancidity or off odor/aroma up to 21 days of storage [24]. Nathappan et al. [25] also reported declining trends in odor scores of stored mutton $\left(5^{\circ} \mathrm{C} \pm 1^{\circ} \mathrm{C}\right)$ with the advancement of the storage period, and the scores also remained within the limit of acceptability up to $72 \mathrm{~h}$ of storage.

\section{Sensory evaluation}

The results of the sensory evaluation are presented in Table-5. The color and appearance scores were significantly higher $(\mathrm{p}<0.05)$ in $\mathrm{T}-3$ and $\mathrm{T}-4$, both at beginning (day 1) and at the end (day 15) of the storage period. However, in general, the scores for color decreased in all the samples as the storage advanced. At the end of storage, the scores for color and appearance were highest for T-3 (7.00) followed by T-4 (6.80), T-2 (5.70), and T-1 (5.50). The results were inconsistent with the findings of Lalchamliani et al. [20] in Vawksa rep meat samples stored at $4^{\circ} \mathrm{C} \pm 1^{\circ} \mathrm{C}$. Under vacuum packaging conditions, meat is protected from color fading due to the low level of oxygen [26]. Both the cured CS and DS (T-3 and T-4) RTE Vawksa rep showed superior flavor scores as compared to the uncured CS and DS (T-1 and T-2). The flavor scores also followed a declining trend starting from beginning till the end of the storage period, which might be due to increase in TBA, TPC, and coliform count. Overall the flavor scores were significantly higher $(\mathrm{p}<0.05)$ in T-3 and T-4 on all the storage days. Devatkal et al. [27] reported that there is deterioration of flavor due to microbial growth and oxidative rancidity in restructured pork rolls. As the storage period is advanced, the sharp decline in flavor scores might be due to oxidation of fat [28], liberation of fatty acids [29] and increased microbial load [30]. Both CS (T-1 and T-3) RTE Vawksa rep registered high texture scores as compared to the DS (T-2 and T-4) RTE Vawksa rep. Texture also followed declining trend throughout the storage in all the samples. Azad [31] also reported that during storage of smoked buffalo meat at $0^{\circ} \mathrm{C}$ and $-4^{\circ} \mathrm{C}$, it started losing color, texture, and odor. On all the storage days, juiciness was found to be significantly higher $(\mathrm{p}<0.05)$ in $\mathrm{T}-3$ and $\mathrm{T}-4$ batches than $\mathrm{T}-1$ and $\mathrm{T}-2$. Throughout the storage period, highest juiciness was observed in T-4 among the different samples. Overall, juiciness scores declined progressively from $1^{\text {st }}$ to $15^{\text {th }}$ day of storage, which might be due to significant $(\mathrm{p}<0.05)$ increase in hardness values in all the samples. Kumar et al. [15] also observed a significant decrease in flavor, texture, and juiciness of pork nuggets during storage. Decrease in texture and juiciness of samples might be due to loss of moisture during the storage. The overall acceptability was significantly higher $(\mathrm{p}<0.05)$ in T-3 on all the storage days. Both the cured CS and DS (T-3 and T-4) RTE Vawksa rep had registered higher overall acceptability as compared to their uncured counterparts, i.e. CS and DS (T-1 and T-2). In general, overall acceptability decreased in all the samples as the storage period advanced. These findings are in

Table-4: Odor scores of Vawksa rep (smoked pork product) stored under vacuum packaging conditions at $4^{\circ} \mathrm{C} \pm 1^{\circ} \mathrm{C}$.

\begin{tabular}{lcccc}
\hline Treatments/Days & $\mathbf{1}$ & $\mathbf{5}$ & $\mathbf{1 0}$ & $\mathbf{1 5}$ \\
\hline $\mathrm{T}-1$ & $9.20 \pm 0.05^{\mathrm{aA}}$ & $8.50 \pm 0.05^{\mathrm{bB}}$ & $6.70 \pm 0.05^{\mathrm{cB}}$ & $6.20 \pm 0.05^{\mathrm{dB}}$ \\
$\mathrm{T}-2$ & $9.40 \pm 0.05^{\mathrm{aA}}$ & $8.40 \pm 0.05^{\mathrm{bB}}$ & $6.50 \pm 0.05^{\mathrm{cB}}$ & $6.10 \pm 0.09^{\mathrm{dB}}$ \\
$\mathrm{T}-3$ & $9.60 \pm 0.05^{\mathrm{aA}}$ & $9.50 \pm 0.05^{\mathrm{abA}}$ & $8.30 \pm 0.05^{\mathrm{cA}}$ & $7.80 \pm 0.05^{\mathrm{dA}}$ \\
$\mathrm{T}-4$ & $9.60 \pm 0.05^{\mathrm{aA}}$ & $9.40 \pm 0.05^{\mathrm{abA}}$ & $8.20 \pm 0.05^{\mathrm{cA}}$ & $7.60 \pm 0.05^{\mathrm{dAB}}$ \\
\hline
\end{tabular}

$\mathrm{n}=27$, mean \pm SE with different superscripts row wise (small alphabets) and column wise (capital alphabets) differ significantly $(p<0.05)$. SE $=$ Standard error 
Table-5: Sensory properties of Vawksa rep (smoked pork product) stored under vacuum packaging conditions at $4^{\circ} \mathrm{C} \pm 1^{\circ} \mathrm{C}$.

\begin{tabular}{|c|c|c|c|c|}
\hline Treatments/Days & 1 & 5 & 10 & 15 \\
\hline \multicolumn{5}{|l|}{ Color and appearance } \\
\hline $\mathrm{T}-1$ & $6.20 \pm 0.05^{\mathrm{aB}}$ & $6.00 \pm 0.14^{\mathrm{bA}}$ & $5.80 \pm 0.12^{\mathrm{aB}}$ & $5.50 \pm 0.15^{\mathrm{aB}}$ \\
\hline $\mathrm{T}-2$ & $6.50 \pm 0.09^{\mathrm{aB}}$ & $6.30 \pm 0.05^{\mathrm{aB}}$ & $6.00 \pm 0.14^{\mathrm{bB}}$ & $5.70 \pm 0.08^{\mathrm{cB}}$ \\
\hline $\mathrm{T}-3$ & $7.50 \pm 0.18^{\mathrm{aA}}$ & $7.30 \pm 0.09^{a b A}$ & $7.20 \pm 0.09^{a b A}$ & $7.00 \pm 0.05^{\mathrm{bA}}$ \\
\hline $\mathrm{T}-4$ & $7.30 \pm 0.09^{\mathrm{aA}}$ & $7.10 \pm 0.05^{\mathrm{abA}}$ & $7.00 \pm 0.14^{\mathrm{abA}}$ & $6.80 \pm 0.12^{\mathrm{bA}}$ \\
\hline \multicolumn{5}{|l|}{ Flavor } \\
\hline $\mathrm{T}-1$ & $6.20 \pm 0.05^{\mathrm{aB}}$ & $6.00 \pm 0.05^{\mathrm{aB}}$ & $5.70 \pm 0.05^{\mathrm{bB}}$ & $5.40 \pm 0.09^{\mathrm{cB}}$ \\
\hline $\mathrm{T}-2$ & $6.00 \pm 0.18^{\mathrm{aB}}$ & $5.80 \pm 0.09^{a B}$ & $5.40 \pm 0.05^{\mathrm{bc}}$ & $5.20 \pm 0.09^{\mathrm{bB}}$ \\
\hline$T-3$ & $7.60 \pm 0.05^{\mathrm{aA}}$ & $7.30 \pm 0.07^{\mathrm{bA}}$ & $7.10 \pm 0.03^{\mathrm{bcA}}$ & $7.00 \pm 0.14^{\mathrm{cA}}$ \\
\hline $\mathrm{T}-4$ & $7.40 \pm 0.12^{\mathrm{aA}}$ & $7.20 \pm 0.09^{a b A}$ & $7.00 \pm 0.14^{\mathrm{bA}}$ & $6.90 \pm 0.03^{\mathrm{bA}}$ \\
\hline \multicolumn{5}{|l|}{ Texture } \\
\hline $\mathrm{T}-1$ & $6.60 \pm 0.07^{\mathrm{aB}}$ & $6.50 \pm 0.14^{\mathrm{aB}}$ & $6.00 \pm 0.07^{\text {bв }}$ & $5.80 \pm 0.05^{\mathrm{bBC}}$ \\
\hline $\mathrm{T}-2$ & $6.40 \pm 0.05^{\mathrm{aB}}$ & $6.20 \pm 0.07^{b c}$ & $5.90 \pm 0.05^{\mathrm{cBC}}$ & $5.70 \pm 0.05^{d c}$ \\
\hline $\mathrm{T}-3$ & $7.60 \pm 0.05^{\mathrm{aA}}$ & $7.40 \pm 0.05^{\mathrm{abA}}$ & $7.20 \pm 0.09^{\mathrm{bcA}}$ & $7.00 \pm 0.13^{\mathrm{cA}}$ \\
\hline $\mathrm{T}-4$ & $7.40 \pm 0.07^{\mathrm{aA}}$ & $7.30 \pm 0.05^{\mathrm{aA}}$ & $7.10 \pm 0.05^{\mathrm{bAB}}$ & $6.80 \pm 0.05^{\mathrm{CAB}}$ \\
\hline \multicolumn{5}{|l|}{ Juiciness } \\
\hline $\mathrm{T}-1$ & $6.50 \pm 0.13^{\mathrm{aB}}$ & $6.30 \pm 0.09^{a b B}$ & $6.20 \pm 0.09^{a b B}$ & $6.00 \pm 0.13^{\mathrm{bB}}$ \\
\hline $\mathrm{T}-2$ & $6.60 \pm 0.03^{\mathrm{aB}}$ & $6.50 \pm 0.05^{\mathrm{aB}}$ & $6.30 \pm 0.05^{\mathrm{bB}}$ & $6.10 \pm 0.09^{\mathrm{cB}}$ \\
\hline $\mathrm{T}-3$ & $7.40 \pm 0.09^{\mathrm{aA}}$ & $7.20 \pm 0.05^{\mathrm{aA}}$ & $6.90 \pm 0.09^{\mathrm{bA}}$ & $6.70 \pm 0.09^{\mathrm{bA}}$ \\
\hline $\mathrm{T}-4$ & $7.50 \pm 0.05^{\mathrm{aA}}$ & $7.30 \pm 0.12^{\mathrm{abA}}$ & $7.00 \pm 0.14^{\mathrm{bcA}}$ & $6.80 \pm 0.13^{\mathrm{CA}}$ \\
\hline \multicolumn{5}{|l|}{ Overall acceptability } \\
\hline $\mathrm{T}-1$ & $6.50 \pm 0.15^{\mathrm{aB}}$ & $6.30 \pm 0.05^{\mathrm{abc}}$ & $6.00 \pm 0.13^{\text {вв }}$ & $5.50 \pm 0.09^{с в}$ \\
\hline $\mathrm{T}-2$ & $6.30 \pm 0.05^{\mathrm{aB}}$ & $6.00 \pm 0.14^{\mathrm{bD}}$ & $5.80 \pm 0.09^{\mathrm{bB}}$ & $5.30 \pm 0.05^{\mathrm{cB}}$ \\
\hline$T-3$ & $7.80 \pm 0.05^{\mathrm{aA}}$ & $7.60 \pm 0.09^{a A}$ & $7.30 \pm 0.02^{\mathrm{bA}}$ & $7.00 \pm 0.13^{\mathrm{aA}}$ \\
\hline $\mathrm{T}-4$ & $7.50 \pm 0.13^{\mathrm{aA}}$ & $7.30 \pm 0.05^{\mathrm{abB}}$ & $7.10 \pm 0.05^{\mathrm{bA}}$ & $6.80 \pm 0.09^{\mathrm{cA}}$ \\
\hline
\end{tabular}

$\mathrm{n}=18$, mean \pm SE with different superscripts row wise (small alphabets) and column wise (capital alphabets) differ significantly $(p<0.05) . S E=$ Standard error

Table-6: Economics of Vawksa rep (smoked pork product).

\begin{tabular}{lcc}
\hline Commodities used & Cured (Rs.) & Uncured (Rs.) \\
\hline Pork $(25 \mathrm{~kg})$ & 6250.00 & 6250.00 \\
Salt and sugar & 26.25 & - \\
Nitrate and nitrite & 17.00 & - \\
Spice mix & 150.00 & - \\
Yoghurt & 100.00 & - \\
STPP & 93.00 & - \\
Packaging & 20.00 & 20.00 \\
Sawdust/wood & 20.00 & 20.00 \\
Electricity & 63.00 & 63.00 \\
Total cost (25 kg) & 6739.25 & 6353.00 \\
Cost/kg & 269.57 & 254.12 \\
\hline
\end{tabular}

STPP=Sodium tripolyphosphate

agreement with the report of Iwanegbe et al. [32], who also observed significant differences $(p<0.05)$ among the treatments groups (different cures, storage periods, and storage temperatures) in terms of color, flavor, juiciness, tenderness, and overall acceptability of smoked rabbit meat.

\section{Production economics of cured versus uncured Vawksa rep}

The comparative cost for the formulation of each of $25 \mathrm{~kg} \mathrm{CS}$ (T-1 and T-3) and DS (T-2 and T-4) is presented in Table-6. It includes the cost of raw materials required, viz., cost of raw pork, curing ingredients (salt, sugar, nitrate, and nitrite), spice mix, yoghurt, STPP, packaging, saw dust/wood, and electricity. The cost of production of cured CS and DS RTE Vawksa rep was estimated to be Rs. $269.57 / \mathrm{kg}$, whereas for uncured CS and DS RTE Vawksa rep, it was Rs $254.12 / \mathrm{kg}$. The expenditure incurred toward equipment and labor was not considered. The production cost of cured CS and DS RTE Vawksa rep was somewhat higher than the uncured CS and DS RTE Vawksa rep, but at the same time, it is much lower than the present market price of Vawksa rep in Aizawl city. Considering the above beneficial attributes superior in terms of sensory, physico-chemical, and most importantly the microbiological qualities of CS and DS RTE Vawksa rep, it would command higher market demand and price in comparison to the uncured CS and DS RTE Vawksa rep, because nowadays, consumers are more quality conscious and ready-to-pay more for the better quality products. Besides, production technology, up-gradation of traditional meat food products is the need of the hour as these products suit to the taste and flavor of local populates.

\section{Conclusion}

From the above study, it can be concluded that using combination of curing, cooking, and smoking, a new and quality assured RTE Vawksa rep could be developed. Compared to uncured CS and DS (T-1 and T-2), the cured CS and DS (T-3 and T-4) RTE Vawksa rep registered superior physico-chemical properties (higher cooking yield, favorable $\mathrm{pH}$, lower TV, and lower TBA values), sensory properties (higher odor scores, higher color, flavor, texture, juiciness, and overall acceptability scores), and microbiological properties (lower TPC, absence of 
colititer, and E. coli count) throughout the storage period of 15-day. Furthermore, cured CS and DS RTE Vawksa rep could be prepared easily with little technology up-gradation and with a negligible escalation of production cost.

\section{Authors' Contributions}

The present study was a part of DD's original research work during his M.V.Sc. thesis program. $\mathrm{PH}$ helped in designing of the work and gave the guidelines during experimental study. LC assisted in the processing of samples. TPS, PS, and ST assisted in statistical analysis, interpretation of the results and drafting of the manuscript. All the authors have read and approved the final manuscript.

\section{Acknowledgments}

The authors are thankful to the Dean, College of Veterinary Sciences and Animal Husbandry, CAU, Selesih, Aizawl, Mizoram, India, for providing the necessary infrastructure required for conducting this research work.

\section{Competing Interests} interests.

The authors declare that they have no competing

\section{References}

1. Singh, P., Sahoo, J., Chatli, M.K. and Biswas, A.K. (2014) Shelf life evaluation of raw chicken meat emulsion incorporated with clove powder, ginger and garlic paste as natural preservatives at refrigerated storage $\left(4 \pm 1^{\circ} \mathrm{C}\right)$. Int. Food Res. J., 21(4): 1363-1373.

2. Llave, Y., Suzuki, A., Fukuoka, M., Umiuchi, E. and Sakai, N. (2015) Migration of smoke components into pork loin ham during processing and storage. J. Food Eng., 166: 221-229.

3. Gomez-Estaca, J., Gomez-Guillen, M.C., Montero, P., Sopelana, P. and Guillen, M.D. (2011) Oxidative stability, volatile components and polycyclic aromatic hydrocarbons of cold-smoked sardine (Sardine pilchardus) and dolphinfish (Coryphaena hippurus). Food Sci. Technol., 44: 1517-1524.

4. Corzo, O., Bracho, N., Rodríguez, J. and Arias, J.M. (2015) Optimizing salting and smoking of Catfish (Bagre Marinus) using response surface methodology. J. Aquat. Food Prod. Technol., DOI: 10.1080/10498850.2013.855286.

5. Sharma, B.D. and Kumar, R.R. (2013) Optimizing shelf life of meat and meat products using innovative packaging solutions. Proceedings of $5^{\text {th }}$ Annual Conference and National Symposium of Indian Meat Science Association (IMSACON-V) on 'Emerging Technological Changes to Meet the Demands of Domestic and Export Meat Sector', 07-09 February, 2013. National Research Centre on Meat, Chengicherla, Hyderabad. p59-71.

6. Chaudhari, S.P., Tiwari, J.G. and Roychaudhury, P. (2007) Occurrence of Escherichia coli in smoked meat. Indian $J$. Anim. Sci., 77(6): 442-445.

7. Bendall, J.R. (1973) Postmortem changes in muscle. In: Bourne, G.H., editor. The Structure and Function of Muscle. Academic Press, New York, NY. p244-306.

8. Pearson, D. (1968) Application of chemical methods for the assessment of beef quality and methods related to protein breakdown. J. Sci. Food Agric., 19(2): 357-363.

9. Witte, V.C., Krause, G.F. and Bailey, M.E. (1970) A new extraction method for determining 2 Thiobarbituric acid values of pork and beef during storage. J. Food Sci., 35(5): 582-585.

10. APHA. (1992) Standard Methods for the Examination of Water and Wastewater. $18^{\text {th }}$ ed. American Public Health Association Inc., Washington, DC.

11. Keeton, J.T. (1983) Effect of fat and NaCL/phosphate levels on the chemical and sensory properties of pork patties. J. Food Sci., 48(3): 878-881.

12. Snedecor, G.W. and Cochran, W.G. (1995), Statistical Methods. $8^{\text {th }}$ ed. Oxford and IBH Publishing, New Delhi.

13. Kanithaporn, P., Gadgil, P., Terry, A.H., Melvin, C.H. and Scott, S.J. (2011) Heterocyclic amine content in commercial ready to eat meat products. J. Meat Sci., 88: 227-233.

14. Arnim, F. and Marlida, Y. (2012) The effect of liquid smoke utilization as preservative for meat balls quality. Pak. $J$. Nutr., 11(11): 1078-1080.

15. Kumar, B.R., Kalaokannan, A. and Radhakrishnan, K.T. (2007) Studies on processing and shelf life of pork nuggets with liquid whey as replacer for added water. Am. J. Food Technol., 2(1): 38-43.

16. Karabagias, I., Badeka, A. and Kontominas, M.G. (2011) Shelf life extension of lamb meat using thyme or oregano essential oils and modified atmosphere packaging. Meat Sci., 88: 109-116.

17. Jay, J.M., Loessner, J.M. and Golden, D.A. (2005) Modern Food Microbiology. $7^{\text {th }}$ ed. Springer Publications, New York, NY. p101-118.

18. Garcia-Esteban, M., Ansorena, D. and Astiasarán, I. (2004) Comparison of modified atmosphere packaging and vacuum packaging for long period storage of dry-cured ham: Effects on colour, texture and microbiological quality. Meat Sci., 67(1): 57-63.

19. Cilla, I., Martínez, L., Beltrán, J.A. and Roncalés, P. (2006) Dry-cured ham quality and acceptability as affected by the preservation system used for retail sale. Meat Sci., 73(4): 581-589.

20. Lalchamliani, L., Hazarika, P., Singh, T.P. and Talukder, S. (2015) Effects of curing ingredients and nisin on product characteristics of Vawksa rep (smoked pork product). J. Nutr. Food Sci., 45(4): 634-645.

21. Kumar, M. and Sharma, B.D. (2003) Quality characteristics of low-fat ground pork patties containing milk co-precipitate. Asian Aust. J. Anim. Sci., 6(4): 588-595.

22. Irkin, R., Esmer, O.K., Degirmencioglu, N. and Degirmencioglu, A. (2011) Influence of packaging conditions on some microbial properties of minced beef meat at $4^{\circ} \mathrm{C}$ storage. Bulg. J. Agric. Sci., 17(5): 655-663.

23. Lawrie, R.A. (1991) The eating quality of meat. In: Meat Science. $5^{\text {th }}$ ed. Pergamon Press, New York, NY. p56-60.

24. Bullock, K.B., Huffman, D.L., Egbert, W.B., Mikel, W.B., Bradford, D.D. and Jones, W.R. (1994) Storage stability of low-fat ground beef made with lower value cuts of beef. J. Food Sci., 59(1): 6-9.

25. Nathappan, M., Kolsalaraman, V.R. and Ramamurthi, R. (1985) A study of certain physic chemical changes in stored mutton in relation to odour score. Cheiron, 14: 2 .

26. Parra, V., Viguera, J., Sánchez, J., Peinado, J., Espárrago, F., Gutierrez, J.I. and Andrésa, A.I. (2012) Effect of exposure to light on physico-chemical quality attributes of sliced drycured Iberian ham under different packaging systems. Meat Sci., 90: 236-243.

27. Devatkal, S., Mendiratta, S.K. and Anjaneyulu, A.S.R. (2003) Effect of calcium lactate on the quality and shelf life of restructured pork rolls. J. Meat Sci., 1: 1-6.

28. Santamaria, L., Lizarraga, T., Astiasaran, I. and Bello, J. (1992) Characterization of pamplona chorizo sausages, physico-chemical and sensory studies. Rev. Esp. Cien. Tec. Ali., 32: 431-445.

29. Branen, A.L. (1979) Interaction of fat oxidation and microbial spoilage in muscle foods. Proceedings of the $31^{\text {st }}$ Annual Reciprocal Meat Conference. p156-161. 
30. Sahoo, J. and Anjaneyulu, A.S.R. (1997) Effect of natural antioxidants and vacuum packaging on the quality of buffalo meat nuggets during refrigerated storage. Meat Sci., 47(3-4): 223-230.

31. Azad, Z.R.A. (2012) Role of smoking on the textural characteristics and shelf-life of buffalo meat. J. Ind. Res.
Technol., 2(2): 98-103.

32. Iwanegbe, I., Iwanegbi, A.I., Ebabhamiegbebho, P.A. and Bello, Y.O. (2011) Effect of cures and storage periods on the sensory and microbial evaluation of smoke - Dried vacuum packaged meat products. Pak. J. Nutr., 10(11): 1032-1035.

$* * * * * * * *$ 